\title{
Challenges of Strawberry Production in High-pH Soil at High Elevation in the Southwestern United States
}

\author{
Shengrui Yao ${ }^{1}$ and Steve Guldan \\ Department of Plant and Environmental Sciences, New Mexico State \\ University (NMSU) Sustainable Agriculture Science Center, 371 County \\ Road 40, P.O. Box 159, Alcalde, NM 87511
}

Robert Flynn

NMSU Agricultural Science Center, Artesia, NM 88210

\section{Carlos Ochoa} Department of Animal and Rangeland Sciences, Oregon State University,
Corvallis, OR 97331

Additional index words. Fragaria $\times$ ananassa, winter survival, yield, high $\mathrm{pH}$ tolerance, planting system

\begin{abstract}
In 2011, 16 strawberry cultivars were planted with two planting systems-a black-plastic-covered perennial system (BP) and a matted-row system (MR) - arranged in a split-block design with four replications at the New Mexico State University (NMSU) Sustainable Agriculture Science Center, Alcalde, NM. Cultivars varied greatly in their yield and tolerance to high-pH soil. 'Allstar', 'Chandler', and 'Darselect' were the three most sensitive cultivars to high soil $\mathbf{p H}$ among the $\mathbf{1 6}$ cultivars tested, whereas 'Wendy', 'Brunswick', 'Honeoye', and 'Clancy' were the four most tolerant cultivars by the end of July 2011. Two to three applications of $0.67 \mathrm{~g} \cdot \mathrm{m}^{-1}$ (linear row) FeEDDHA were used per year through fertigation to effectively treat leaf chlorosis resulting from high soil $\mathrm{pH}$. After averaging the yields of 2012 and 2013, 'Mesabi' and 'Kent' had greater yield than others and twice the yield of 'Jewel'. Early cultivars Earliglow and Annapolis and late cultivars L'Amour and Ovation all had low yields in both years. In Jan. 2013, the minimum temperature reached $-21.7^{\circ} \mathrm{C}$, which caused crown damage to some cold-tender cultivars, especially in the black-plastic-covered system. 'Wendy', 'Chandler', 'Clancy', and 'Jewel' were the cold-tender cultivars, whereas 'Mesabi', 'Kent', 'Cavendish', and 'Honeoye' were the hardiest among those tested. Despite repeated late frosts from 19 Apr. to 4 May 2013 and a delayed harvest season, most cultivars produced greater yield than in 2012 with 'Mesabi' and 'Kent' being the greatest. There were no significant differences in yields in 2012 and 2013 between BP and MR treatments, but yield in BP was significantly lower than in MR in 2014. With appropriate cultivar selection and management, growers can produce strawberries in high-pH soil at high elevation with a short growing season in the Southwest.
\end{abstract}

In the United States, strawberries are mainly grown commercially in Florida and California, but most other regions - especially near metropolitan areas - have their own strawberry production (Guan et al., 2013; USDA-National Agriculture Statistics Service,

Received for publication 12 Aug. 2014. Accepted for publication 13 Nov. 2014.

Funding for this research was provided by the U.S. Department of Agriculture Specialty Crop Block Grant program, the New Mexico Department of Agriculture Agricultural Promotion and Development Grant program, and the New Mexico Agricultural Experiment Station.

We thank David Salazar, David Archuleta, Marcos Romero, Estevan Herrera, Margarito Hernandez, Rumaldo Roybal, Bingye Xue, Junxin Huang, and Robert Heyduck for their technical assistance. We also thank Geno Picchioni and Richard Heerema from New Mexico State University and the anonymous reviewers for their helpful suggestions.

${ }^{1}$ To whom reprint requests should be addressed; e-mailyaos@nmsu.edu. and the shipping of dormant plants itself could be problematic, especially for those areas without local berry nurseries. In Utah, June-bearing cultivar Chandler grown in high tunnels was profitable, but the ever-bearing cultivars in high tunnels were not (Rowley et al., 2010, 2011).

Strawberry cultivar adaptation, in comparison with other fruit crops such as apples and peaches, tends to be more localized geographically. Each area has its own best performers adapted to its soil, weather conditions, and pest/disease pressures (Weber, 2005; Yao et al., 2009). Strawberry cultivars have changed more rapidly than any other fruit crop, and this trend will continue in the future (Hokanson and Finn, 2000). There are several active strawberry breeding programs in North America and quite a few new cultivars were released within the past 10 years (Jamieson, 2003; Jamieson et al., 2004a, 2004b, 2009; Lewers et al., 2004; Luby et al., 2003). With different genetic backgrounds, cultivar adaptation or tolerance to adverse soil conditions is expected to differ.

High frequency and intensity of late spring frosts in semiarid climates have made fruit production challenging in these areas (Yao et al., 2011). Growers may only harvest five to six apple crops during a 10 -year period, and as a result, many have been forced to abandon their orchards. To help these growers stay in business, alternative crops are needed. Strawberry is a possible alternative crop because it matures early and is relatively easy to produce, but late spring frosts still have the potential to delay or reduce harvest. In general, strawberries prefer slightly acidic soil and often exhibit leaf chlorosis in high-pH soils (Luby et al., 2003; Renquist and Hughes, 1985). Research on strawberries in high-pH soil conditions is limited (Renquist and Hughes, 1985; Rowley et al., 2010; Zaiter et al., 1993) and some of the older cultivars with research data are no longer commercially available.

We set up a strawberry experiment with 16 cultivars and two perennial planting systems at the NMSU Sustainable Agriculture Science Center at Alcalde with three objectives: evaluate cultivars' tolerance to high-pH soil, determine yield potential in high-pH soil, and compare two perennial planting systems for high-elevation areas in the Southwest.

\section{Material and Methods}

On 5 May 2011, 16 strawberry cultivars were planted with two planting system treatments-BP and MR-in a split-block design with four replications and planting system as the main block and cultivar as the subblock at NMSU's Sustainable Agriculture Science Center, Alcalde, NM (lat. $36^{\circ} 05^{\prime} 27.94^{\prime \prime} \mathrm{N}$, long. $106^{\circ} 03^{\prime} 24.56^{\prime \prime} \mathrm{W}$, and $1737 \mathrm{~m}$ elevation). Both planting systems were on raised beds 15 to $18 \mathrm{~cm}$ in height and $\approx 60 \mathrm{~cm}$ in width. The soil was a Fruitland sandy loam with soil $\mathrm{pH} 8.0$ to $8.1\left(1: 1 \mathrm{H}_{2} \mathrm{O}\right)$ and $1.7 \%$ organic matter. Plots were $3 \mathrm{~m}$ long and rows were $1.2 \mathrm{~m}$ apart from center to center. Each row had eight 3.0-m plots (one cultivar/ 
plot) with $0.9 \mathrm{~m}$ of space between plots. For the MR system, there were six plants spaced $45 \mathrm{~cm}$ apart in a row in each plot. For the BP system, there were 18 plants in double rows with staggered planting with $30-\mathrm{cm}$ spacing between plants and $30-\mathrm{cm}$ spacing between rows. The 16 cultivars were Allstar, Annapolis, Brunswick, Cabot, Cavendish, Chandler, Clancy, Darselect, Earliglow, Honeoye, Jewel, Kent, L'Amour, Mesabi, Ovation, and Wendy. One drip irrigation line per row in the middle of the bed with emitters $30 \mathrm{~cm}$ apart $\left(1.13 \mathrm{~L} \cdot \mathrm{h}^{-1}\right)$ was installed at planting, and another line was added in Spring 2013. Both lines lay in the middle of the bed, 12 to $15 \mathrm{~cm}$ apart. Irrigation was turned on once or twice per week for $4 \mathrm{~h}$ each time during the growing season depending on season and precipitation. Hand weeding was conducted for the MR treatment as necessary. Runners were removed two to three times each year for the BP treatment.

Fertility management and leaf sampling. To evaluate cultivar tolerance to high soil $\mathrm{pH}$, leaf chlorosis was monitored. Leaf color was measured with a Minolta chlorophyll meter SPAD-502 (Spectrum Technologies, Aurora, IL) on 4 July, 30 July, and 3 Sept. 2011; 19 May and 5 Sept. 2012; and 22 June 2013. For each plot, 15 readings were taken on newly expanded leaves, and the results were averaged.

To correct leaf chlorosis, $6 \%$ chelated iron (FeEDDHA) was applied twice through fertigation, on 5 Aug. and 15 Aug. 2011, at $0.33 \mathrm{~g} \cdot \mathrm{m}^{-1}$ linear row to all treatments. In 2012, FeEDDHA was applied at $0.67 \mathrm{~g} \cdot \mathrm{m}^{-1}$ linear row on 19 June and 7 Aug., for a total of $1.33 \mathrm{~g} \cdot \mathrm{m}^{-1}$ linear row. In addition, FeEDDHA was applied at $0.67 \mathrm{~g} \cdot \mathrm{m}^{-1}$ linear row on $23 \mathrm{Apr}$. and 22 May 2013 and $0.33 \mathrm{~g} \cdot \mathrm{m}^{-1}$ on 10 Aug. 2013 for a total of $1.68 \mathrm{~g} \cdot \mathrm{m}^{-1}$ linear row.

Twenty young, fully expanded leaves with petioles removed were collected from two blocks of both treatments and from all 16 cultivars on 25 June 2012 and 28 June 2013. Samples were dried in an oven at $65{ }^{\circ} \mathrm{C}$ for $48 \mathrm{~h}$ and analyzed for nutrient concentrations (Campbell and Plank, 1991; U.S. Environmental Protection Agency Method 6010A, 1992). A total of $28 \mathrm{~kg}$ nitrogen $(\mathrm{N}) / \mathrm{ha}$ was applied through weekly fertigation by alternating between $46 \mathrm{~N}-0 \mathrm{P}-0 \mathrm{~K}$ and $24 \mathrm{~N}-8 \mathrm{P}-16 \mathrm{~K}$ in Spring 2012. After leaf analysis, ammonium sulfate $(21 \mathrm{~N}-0 \mathrm{P}-0 \mathrm{~K})$ was used as a nitrogen and sulfur source and was applied weekly in alternation with $24 \mathrm{~N}-8 \mathrm{P}-16 \mathrm{~K}$ for 4 to 6 weeks from July to Aug. 2012 for a total rate of $22.4 \mathrm{~kg} \mathrm{~N} / \mathrm{ha}$, and from Apr. to May 2013, for a total rate of $33.6 \mathrm{~kg}$ N/ha. In Summer 2013 to Spring 2014, a similar fertilizer program was applied as in Summer 2012 to Spring 2013.

Winter survival evaluation. Strawberry winter survival was visually evaluated in the field on 30 Mar. and 13 Apr. 2013 and 16 Apr. 2014. The degree of damage assessment was taken for each plant in the BP treatment, and the results were averaged by plot. The criteria were $0=$ no growing point from the group of crowns from one original plant, $1=$ one growing point, $2=$ two to three growing points, and $3=$ more than three growing points.

Frost protection and fruit harvest. For the first blooming season in 2012, no frost protection was used. Overhead sprinklers were installed in Fall 2012 and used for late spring frost protection in 2013 and 2014. Fruit were harvested twice per week or as necessary from 21 May to 8 June 2012 and from 31 May to 24 June 2013. In 2014, we harvested the top eight performing cultivars from 30 May to 27 June. 'Honeoye' was chosen over 'Darselect' as a result of its popularity. On each harvest date, the fresh weight of 20 fruit and total fruit weight of each plot were recorded.

Temperature and soil moisture records. To monitor and compare the seasonal variability of soil water content and soil temperature in BP and MR plots, four soil water content sensors (Model 5TE; Decagon Devices Inc., Pullman, WA) were installed in four different plots: two BP plots and two MR plots. Sensors were installed horizontally at $10-\mathrm{cm}$ depth from the top of the raised bed. The sensors were attached to a Decagon EM50 model data logger that was programmed to collect soil volumetric water content and soil temperature every $1 \mathrm{~h}$ from 11 Apr. 2012 to 15 Nov. 2013. Air temperatures were taken from a nearby weather station that was $80 \mathrm{~m}$ from the test plot.

Statistical analyses. Leaf color (SPAD) reading, winter survival, and fruit yield data were analyzed using analysis of variance at $P \leq$ 0.05 with Fisher's protected least significant difference test for mean separation with Statistix 9.0 (Analytical Software, Tallahassee, FL).

\section{Results and Discussion}

Winter/spring air temperatures. From 1 Jan. through 31 Mar. 2012, there were a total of $6 \mathrm{~d}$ with minimum temperature below $-10{ }^{\circ} \mathrm{C}$ (Fig. 1); whereas in 2013, January was much colder and there were also more severe spring frosts in April and early May than in 2012 (Fig. 1). With 8 d below $-15^{\circ} \mathrm{C}$ and a low temperature of $-21.7^{\circ} \mathrm{C}$ on 16 Jan. 2013, there was winter damage to some strawberry cultivars. A low air temperature of $-7.2{ }^{\circ} \mathrm{C}$ on $19 \mathrm{Apr}$. and several subsequent frosts damaged the early flowers.
Cultivar tolerance to high-pH soil. SPAD leaf readings for the 16 strawberry cultivars are presented in Table 1. By the end of July 2011 and before iron product was applied on 5 Aug. 2011, leaf SPAD readings ranged from 11.7 (yellow/white) for 'Allstar' and 15.5 for 'Chandler' to 37.4 (dark green) for 'Wendy' and 34.4 for 'Brunswick' (Fig. 2). 'Wendy', 'Brunswick', 'Honeoye', and 'Clancy' were the top four high-pH-tolerant cultivars, whereas 'Allstar', 'Darselect', and 'Chandler' were the three most sensitive cultivars on 30 July 2011. Although the SPAD reading for 'Mesabi' was also on the lower side in July 2011 (Table 1), this could be the result of its genetic predisposition to "June yellow" (Luby et al., 2003); its leaf color SPAD readings were average or above average among the 16 cultivars in the following years with FeEDDHA applications (Table 1).

Two weeks after FeEDDHA application, leaf color change was visually noticeable (Fig. 2). There was no significant difference in SPAD readings between $B P$ and MR, except in Sept. 2011 when SPAD was higher in MR and in June 2013, the SPAD readings in $\mathrm{BP}$ were higher than those in MR, not long after FeEDDHA applications. At those two dates, the SPAD readings had less variability and significant differences were detected between the two planting systems. There was no significant cultivar $\times$ treatment interaction in SPAD readings. Renquist and Hughes (1985) tested strawberry cultivars in high-pH soil in Colorado. Unfortunately, after 30 years, most of those cultivars were no longer commercially available at the inception of this study. Zaiter et al. (1993) tested FeEDDHA spray for the correction of strawberry leaf chlorosis in highly calcareous soil and reported yield increases for sensitive cultivars in Lebanon. FeEDDHA has also been widely used in other crops to manage high-pH-induced leaf chlorosis (Broschat and Elliot, 2005; Goos and Johnson, 2000; Moraghan, 1991; Schenkeveld et al., 2008). Results from our experiment indicate that FeEDDHA can be applied efficiently through fertigation, and applications of $0.67 \mathrm{~g} \cdot \mathrm{m}^{-1}$ linear row two to three times per year was sufficient to keep all cultivars' leaf color at an acceptable level (SPAD reading over 30 ),

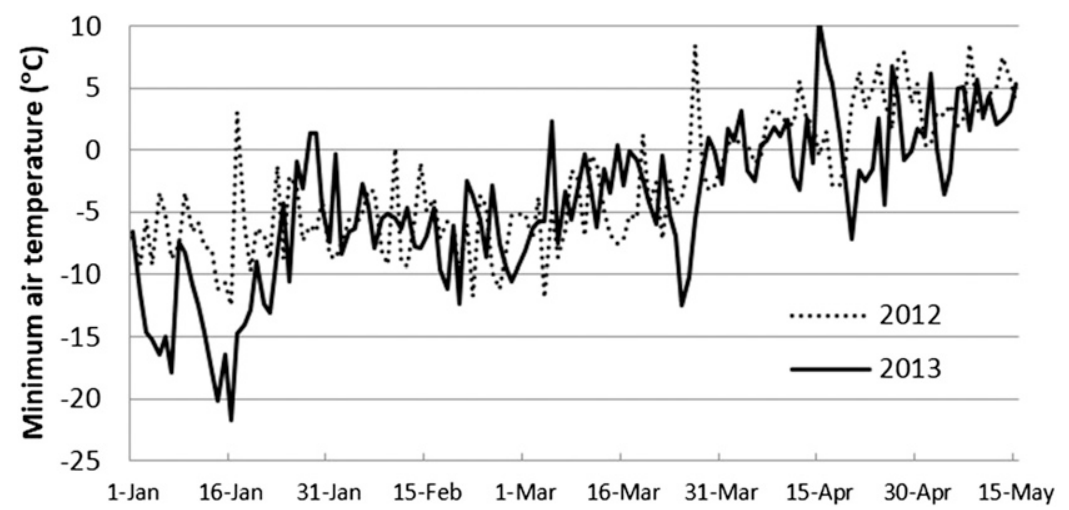

Fig. 1. Minimum daily air temperatures from 1 Jan. to 15 May of 2012 and 2013 at Alcalde, NM. 
except for 'Chandler' on 22 June 2013. However, cultivar selection is still the number one choice for managing leaf chlorosis, like it is with other crops (Goos and Johnson, 2000).

Yield. In 2013, severe late frosts damaged the primary berries and some secondary berries, reset the bloom time for all cultivars, and delayed the harvest season (Table 2); the early yield percentages among cultivars were less variable (38\% to $79 \%$ ) in 2013 than in 2012 ( $1 \%$ to $81 \%$ ) (Table 2 ). However, the total yield for most cultivars was higher than in 2012 (Table 3). In 2014, the overhead sprinklers were turned on early enough (at $34^{\circ} \mathrm{F}$ ) and only minimal frost damage was incurred by all cultivars. Pritts et al. (1999) found that yield was not significantly affected by weevil damage because strawberry cultivars compensated

Table 1. Strawberry cultivar leaf color reading with SPAD meter before and after chelated iron product (FeEDDHA) applications from $2011-13 .^{\mathrm{z}}$

\begin{tabular}{|c|c|c|c|c|c|c|}
\hline \multirow[b]{2}{*}{ Cultivar } & \multicolumn{3}{|c|}{2011} & \multicolumn{2}{|c|}{2012} & \multirow{2}{*}{$\frac{2013}{22 \text { June }}$} \\
\hline & 4 July & 30 July & 3 Sept. & 19 May & 5 Sept. & \\
\hline$\overline{\text { Wendy }}$ & 36.6 & 37.4 & 38.9 & 34.6 & 40.1 & 35.3 \\
\hline Brunswick & 35.4 & 34.4 & 40.1 & 31.6 & 39.5 & 34.7 \\
\hline Honeoye & 33.8 & 33.8 & 38.4 & 31.0 & 38.4 & 32.3 \\
\hline Clancy & 30.9 & 32.4 & 33.9 & 29.1 & 35.6 & 31.7 \\
\hline Kent & 32.0 & 31.3 & 36.3 & 25.3 & 36.8 & 32.8 \\
\hline Annapolis & 31.7 & 31.2 & 39.4 & 30.2 & 39.7 & 33.9 \\
\hline Jewel & 34.9 & 31.0 & 36.9 & 30.5 & 36.7 & 33.4 \\
\hline Cavendish & 34.9 & 30.9 & 39.8 & 33.6 & 41.5 & 35.5 \\
\hline Earliglow & 32.8 & 30.9 & 35.2 & 25.6 & 34.0 & 30.2 \\
\hline Ovation & 31.8 & 30.7 & 35.4 & 29.3 & 35.8 & 32.2 \\
\hline Cabot & 31.9 & 30.1 & 37.8 & 26.4 & 37.0 & 31.8 \\
\hline L'Amour & 29.0 & 27.7 & 34.4 & 29.1 & 34.7 & 30.8 \\
\hline Mesabi & 25.9 & 23.9 & 40.0 & 27.1 & 40.4 & 34.3 \\
\hline Darselect & 25.2 & 22.7 & 34.2 & 21.6 & 35.1 & 31.7 \\
\hline Chandler & 19.8 & 15.5 & 32.0 & 14.5 & 30.3 & 27.3 \\
\hline Allstar & 25.5 & 11.7 & 33.2 & 20.7 & 34.2 & 33.1 \\
\hline Critical value ${ }^{y}$ & 2.88 & 2.74 & 1.3 & 1.83 & 1.27 & 1.3 \\
\hline Average & 30.8 & 28.5 & 36.6 & 27.5 & 36.9 & 32.6 \\
\hline \multicolumn{7}{|l|}{ Treatment } \\
\hline MR & 31.5 & 27.6 & 36.9 & 28.4 & 36.6 & 31.9 \\
\hline BP & 30.0 & 29.3 & 36.3 & 26.7 & 37.1 & 33.2 \\
\hline Critical value & 5.09 & 3.47 & 0.43 & 2.21 & 1.36 & 1.05 \\
\hline
\end{tabular}

${ }^{\mathrm{z}} \mathrm{FeEDDHA}$ was applied on 5 Aug. and 15 Aug. 2011; 19 June and 7 Aug. 2012; and 23 Apr., 22 May, and 10 Aug. 2013.

${ }^{\mathrm{y}}$ For each factor, difference between two values greater than critical value in each column indicates significant difference at $P \leq 0.05$ with Fisher's protected least significant difference test. $\mathrm{BP}=$ black-plastic-covered system; $\mathrm{MR}=$ matted-row system .

by stimulating growth from secondary buds. In this study, late frost damage had greater impact on fruit yield than weevil damage, because it not only damaged flowers and fruitlets, but also flower buds and leaves.

'Cavendish' and 'Mesabi' had the highest yield in 2012 followed by 'Kent', 'Cabot', and 'Jewel', whereas 'Earliglow', 'Clancy', and 'Chandler' had the lowest yield among the 16 cultivars evaluated. The bare root 'Cavendish' plants had more branched crowns than others at planting, which may have contributed to its higher yield in the first harvest season. 'Mesabi' and 'Kent' had significantly higher yield than others in 2013 (Table 3). 'Earliglow' had the lowest yield for both 2012 and 2013, and 'L'Amour', 'Wendy', 'Clancy', and 'Ovation' also had low yield. These results are similar to a cultivar trial in Minnesota, where 'Mesabi', 'Cavendish', 'Brunswick', and 'Kent' had the highest yields, whereas 'Clancy', 'Evangeline', and 'L'Amour' were the three cultivars most sensitive to winter damage and had low yield (Yao et al., 2009). Cultivar performance varies from region to region and from year to year depending on soil and weather conditions (Lewers et al., 2004; Yao et al., 2009). The early blooming of 'Earliglow' and 'Chandler' may have contributed to their low yield, but the blooming time is not the only reason. 'Ovation' and 'L'Amour' were the last two cultivars to bloom in this study, but they also had lower yield compared with 'Mesabi', 'Cavendish', and 'Kent'. Both 'Ovation' and 'L'Amour' had excessive runners, vigorous plants, and limited flower clusters. Overall, 'Mesabi' was the most productive cultivar, producing 16 times more fruit than 'Earliglow' and 1.6 times more than 'Jewel' averaging across 2012 and 2013 . The 2014 harvest also confirmed that 'Kent' and
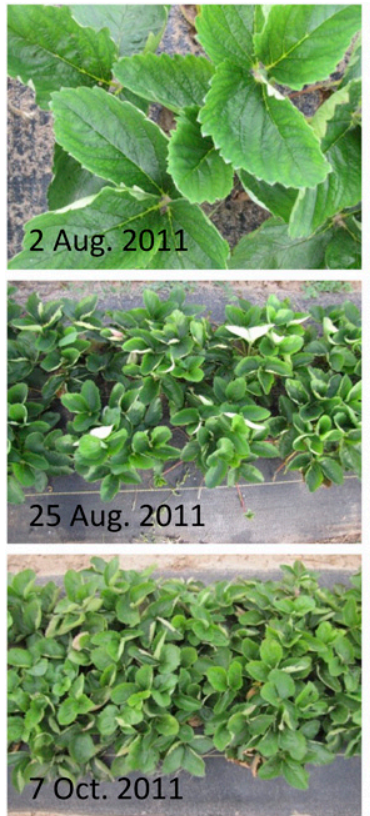

Wendy

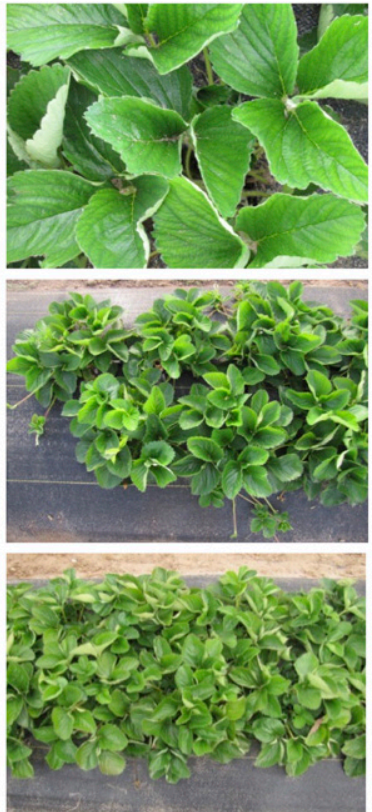

Brunswick
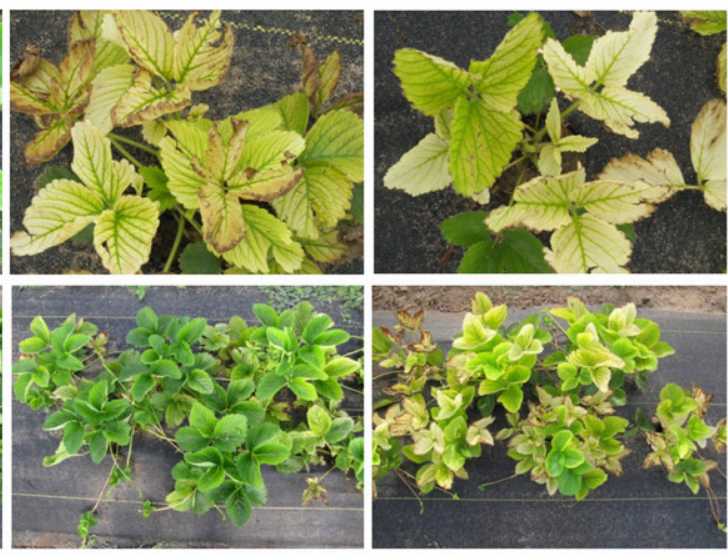

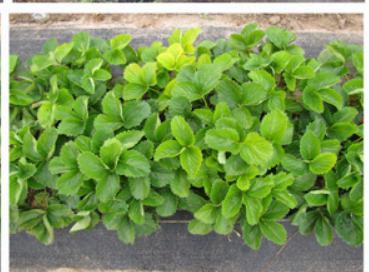

Chandler

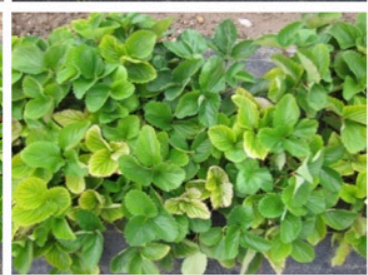

Allstar

Fig. 2. Strawberry leaf color changes before and after FeEDDHA treatment in 2011. FeEDDHA was applied on 5 Aug. and 15 Aug. 2011 at a rate of 0.33 g.m ${ }^{-1}$. 
'Mesabi' were the top performers among the eight cultivars harvested (Table 3 ).

There was no difference in yield between BP and MR treatments in 2012 and 2013. In 2014, partial harvest, however, yield in BP was $28 \%$ lower than in MR (Table 3). Plants in BP declined in the third harvest season of 2014.

There were significant cultivar $\times$ planting system interactions in both 2012 and 2013. In 2012, most cultivars had slightly higher yield in MR treatment, whereas 'Cabot' and 'Cavendish' had higher yield in BP treatment. In 2013, most cultivars again had

Table 2. Early yields of strawberry cultivars in 2012 and 2013.

\begin{tabular}{lcc}
\hline Cultivar & 30 May 2012 (\%) & 10 June 2013 (\%) \\
\hline Brunswick & 81.3 & 78.7 \\
Earliglow & 79.6 & 66.1 \\
Annapolis & 78.3 & 72.9 \\
Allstar & 75.4 & 51.6 \\
Jewel & 74.7 & 63.3 \\
Honeoye & 71.7 & 73.1 \\
Cavendish & 66.9 & 64.7 \\
Wendy & 66.3 & 66.0 \\
Kent & 63.1 & 76.6 \\
Cabot & 58.7 & 41.2 \\
Mesabi & 55.2 & 69.8 \\
Darselect & 46.8 & 59.6 \\
Chandler & 39.8 & 46.3 \\
Ovation & 38.9 & 38.4 \\
Clancy & 25.8 & 45.7 \\
L'Amour & 1.1 & 41.6 \\
Critical & 11.3 & \\
$\quad$ value & & 13.0 \\
\hline
\end{tabular}

${ }^{\text {zPercentage of total yield by the cutoff dates of } 30}$ May 2012 and 10 June 2013.

${ }^{y}$ Difference between two values greater than critical value in each column indicates significant difference at $P \leq 0.05$ with Fisher's protected least significant difference test. similar or slightly higher yield in MR treatment, but 'Mesabi' had higher yield in BP treatment. The higher yield of 'Cabot' and 'Cavendish' in BP treatments in 2012 could be the result of their better original plant quality and establishment, whereas the higher yield of 'Mesabi' in BP in 2013 further proved its good winter-hardiness.

Fruit size. There was no fruit size difference between BP and MR treatments in both 2012 and 2013. The average fruit size in 2013 for all cultivars $(7.3 \mathrm{~g})$ was bigger than in 2012 (6.0 g). 'Cabot', 'Cavendish', and 'Mesabi' had average fruit sizes of 8.6 to $9.1 \mathrm{~g}$ in 2012, whereas in 2013, 'Cabot', 'Clancy', 'L'Amour', 'Mesabi', 'Darselect', and 'Chandler' all had average fruit size from 8.1 to $10 \mathrm{~g}$ (data not shown). 'Earliglow' had the smallest fruit (less than $5 \mathrm{~g}$ ) in both years and would not be marketable. The loss of primary and secondary berries to frosts contributed to the small fruit in this study. Increasing fruit size would be an important topic for future strawberry research in this area.

Winter survival. The winter of 2012-13 damaged the crowns of some cultivars (Table 4); the symptoms were dead crowns or delayed leafing out. On 13 Apr. 2013, even the tender cultivars had more actively growing crowns than on 30 Mar., but their size was small and growth was limited (Table 4). 'Wendy', 'Chandler', 'Clancy', and 'Jewel' were the four most cold-tender cultivars in our study, whereas 'Kent', 'Mesabi', 'Cavendish', 'Honeoye', 'Brunswick', and 'Cabot' were the hardiest cultivars among the 16 tested. Results from 2014 were similar with 'Honeoye', 'Kent', 'Mesabi', and 'Cavendish' having the highest survival and 'Clancy', 'Chandler', and 'Wendy' having the lowest (data not shown). In

Table 3. Strawberry yields of 16 cultivars grown from 2012-14 at Alcalde, NM.

\begin{tabular}{|c|c|c|c|c|c|c|c|c|}
\hline \multirow[b]{2}{*}{ Cultivar } & \multicolumn{2}{|c|}{2012} & \multicolumn{2}{|c|}{2013} & \multicolumn{2}{|c|}{ Avg } & \multicolumn{2}{|c|}{2014} \\
\hline & $\overline{\left(\mathrm{g} \cdot \mathrm{m}^{-1}\right)^{\mathrm{z}}}$ & $\left(\mathrm{kg} \cdot \mathrm{ha}^{-1}\right)$ & $\left(\mathrm{g} \cdot \mathrm{m}^{-1}\right)$ & $\left(\mathrm{kg} \cdot \mathrm{ha}^{-1}\right)$ & $\left(\mathrm{g} \cdot \mathrm{m}^{-1}\right)$ & $\left(\mathrm{kg} \cdot \mathrm{ha}^{-1}\right)$ & $\left(\mathrm{g} \cdot \mathrm{m}^{-1}\right)$ & $\overline{\left(\mathrm{kg} \cdot \mathrm{ha}^{-1}\right)}$ \\
\hline$\overline{\text { Mesabi }}$ & 2,030 & 16,640 & 2,540 & 20,800 & 2,280 & 18,720 & 1,640 & 13,650 \\
\hline Kent & 1,580 & 12,970 & 2,210 & 18,130 & 1,900 & 15,550 & 1,940 & 16,190 \\
\hline Cavendish & 2,060 & 16,920 & 1,050 & 8,640 & 1,560 & 12,780 & 910 & 7,550 \\
\hline Cabot & 1,030 & 8,450 & 820 & 6,720 & 930 & 7,590 & 630 & 5,270 \\
\hline Jewel & 1,010 & 8,310 & 710 & 5,830 & 860 & 7,070 & 610 & 5,070 \\
\hline Brunswick & 850 & 6,980 & 790 & 6,440 & 820 & 6,710 & 970 & 8,120 \\
\hline Darselect & 680 & 5,540 & 820 & 6,710 & 750 & 6,130 & & \\
\hline Allstar & 600 & 4,900 & 640 & 5,250 & 620 & 5,070 & 650 & 5,430 \\
\hline Honeoye & 480 & 3,930 & 610 & 4,990 & 540 & 4,460 & 570 & 4,710 \\
\hline Chandler & 190 & 1,540 & 770 & 6,340 & 480 & 3,940 & & \\
\hline Wendy & 330 & 2,740 & 530 & 4,350 & 430 & 3,550 & & \\
\hline Clancy & 170 & 1,380 & 620 & 5,070 & 390 & 3,220 & & \\
\hline L'Amour & 360 & 2,980 & 410 & 3,360 & 390 & 3,170 & & \\
\hline Annapolis & 380 & 3,130 & 380 & 3,080 & 380 & 3,100 & & \\
\hline Ovation & 370 & 3,070 & 310 & 2,510 & 340 & 2,790 & & \\
\hline Earliglow & 90 & 770 & 170 & 1,430 & 130 & 1,100 & & \\
\hline Critical value $^{\mathrm{y}}$ & 260 & & 217 & & 189 & & 230 & \\
\hline Avg & 760 & 6,270 & 840 & 6,850 & 800 & 6,560 & 990 & 8,250 \\
\hline \multicolumn{9}{|l|}{ Treatment } \\
\hline MR & 790 & 6,500 & 880 & 7,220 & 840 & 6,860 & 1,150 & 9,420 \\
\hline BP & 740 & 6,030 & 790 & 6,490 & 760 & 6,260 & 830 & 6,820 \\
\hline Critical value & 290 & & 220 & & 330 & & 270 & \\
\hline
\end{tabular}

${ }^{\mathrm{z}} \mathrm{g} \cdot \mathrm{m}^{-1}$ was yield in gram per meter row.

${ }^{y}$ For each factor, difference between two values greater than critical value in each column indicates a significant difference at $P \leq 0.05$ with Fisher's protected least significant difference test

$\mathrm{BP}=$ black-plastic-covered system; $\mathrm{MR}=$ matted-row system.

Minnesota, similar results were observed with 'Clancy' as the most sensitive cultivar ('Wendy' was not included in that trial) (Yao et al., 2009). The low yields of 'Wendy', 'Chandler', and 'Clancy' in 2013 could also be partially attributable to their severe winter damage. Plants in the MR system had less winter damage than those in the BP system (data not presented) because plants in the BP system could not have runners and relied on branched crowns of the original plants to fruit, which grew higher and higher above the ground each year after planting. Those branched crowns were exposed in the air and were vulnerable to winter damage and desiccation by spring winds. For the MR system, the branched crowns from the original plants were only a small portion of all producing crowns. Crowns from young runners were closer to the ground and less vulnerable to winter damage. The plastic cover increased the soil temperature (discussed below) and may have caused plants to deharden earlier in winter, which could result in additional winter damage.

Leaf nutrients. In general, leaf nutrients were in a sufficient range (Pritts and Handley, 1998), except for $\mathrm{N}$ and sulfur (data not shown). High-pH soil-sensitive cultivars Allstar and Chandler had higher $\mathrm{N}$ level than others, which may have been the result of their smaller plant size. The $\mathrm{N}$ concentration for the rest of the cultivars was less than $2 \%$. Total leaf iron content was not correlated to leaf chlorosis symptoms in this study, which is similar to previous reports (Smith and Cheng, 2006); leaf color/chlorosis is more related to plant-available iron content, not the total leaf iron content (Smith and Cheng, 2006).

Cultivar comparison. 'Wendy' had the best adaptation to high-pH soil with dark leaf color, but its early bloom and tender plants in winter make it unsuitable for northern New Mexico or similar areas. It would be a good germplasm for breeding high $\mathrm{pH}$-tolerant strawberry cultivars. 'Mesabi' had its genetic "June yellow" during the establishment year, but with FeEDDHA applications, it produced the highest yield in 2012 and 2013, especially in 2013. The cost of FeEDDHA application would be $\$ 40$ to $\$ 60$ per $1000 \mathrm{~m}^{2}$ per year depending on the application rate and price. 'Mesabi' and 'Kent' stood out from others in 2013 and 2014 in terms of yield (Table 3), and this high yield is a good indicator of cultivar adaptation to the local climate, soil conditions, and pest/disease pressures. Comparing results from other regions, strawberry adaptation is localized, and each region has its own best-performing cultivars (Hokanson and Finn, 2000; Yao et al., 2009). 'Allstar' and 'Chandler' were top performers in Maryland, California, and North Carolina (Poling, 1993; Stevens et al., 2007), but they were the most sensitive cultivars to high $\mathrm{pH} /$ high lime soil among the 16 cultivars tested in this study, which impaired their growth and yield potential.

Black-plastic-covered system versus matted-row system. BP treatment kept soil moisture better than the MR treatment (data 
Table 4. Winter survival of strawberry cultivars in a black-plastic-covered system in 2013 at Alcalde, NM. ${ }^{\text {. }}$

\begin{tabular}{lll}
\hline Cultivar & 30 Mar. & $13 \mathrm{Apr}$. \\
\hline Kent & $2.85 \mathrm{a}^{\mathrm{y}}$ & $2.93 \mathrm{ab}$ \\
Mesabi & $2.83 \mathrm{a}$ & $2.90 \mathrm{ab}$ \\
Cavendish & $2.80 \mathrm{a}$ & $2.99 \mathrm{a}$ \\
Honeoye & $2.73 \mathrm{a}$ & $2.89 \mathrm{ab}$ \\
Brunswick & $2.60 \mathrm{ab}$ & $2.74 \mathrm{ab}$ \\
Cabot & $2.55 \mathrm{ab}$ & $2.76 \mathrm{abc}$ \\
L'Amour & $2.28 \mathrm{bc}$ & $2.61 \mathrm{bcde}$ \\
Ovation & $2.18 \mathrm{~cd}$ & $2.75 \mathrm{abc}$ \\
Annapolis & $2.13 \mathrm{cde}$ & $2.69 \mathrm{abcd}$ \\
Allstar & $2.08 \mathrm{cde}$ & $2.27 \mathrm{efg}$ \\
Earliglow & $1.93 \mathrm{cde}$ & $2.49 \mathrm{cdef}$ \\
Darselect & $1.90 \mathrm{de}$ & $2.37 \mathrm{defg}$ \\
Jewel & $1.78 \mathrm{ef}$ & $2.51 \mathrm{cdef}$ \\
Clancy & $1.53 \mathrm{fg}$ & $2.11 \mathrm{gh}$ \\
Chandler & $1.38 \mathrm{~g}$ & $1.77 \mathrm{~h}$ \\
Wendy & $1.20 \mathrm{~g}$ & $2.24 \mathrm{fg}$ \\
\hline
\end{tabular}

${ }^{\mathrm{z}}$ Evaluation criteria: $0=$ no growing point from that group of crowns from one original plant; $1=$ one growing point from that group of crowns; $2=$ two to three growing points from that group of crowns; $3=$ more than three growing points from that group of crowns.

${ }^{y}$ For each factor, values accompanied by the same letter within a column indicate no significant difference at $P \leq 0.05$ with Fisher's protected least significant difference test.

not shown). Growers may water the BP treatment less each time or less often than the MR treatment. Soil temperature ranged from $-4{ }^{\circ} \mathrm{C}$ during the coldest days of mid-January to 30 ${ }^{\circ} \mathrm{C}$ during mid-July of 2013. Data from both pairs of sensors showed that soil temperature was generally higher, by $\approx 1{ }^{\circ} \mathrm{C}$, in $\mathrm{BP}$ compared with MR; this was particularly evident during the coldest days of Jan. 2013 and the hottest days of the summer season of both years.

Based on the 3 harvest years from 2012 to 2014, we would recommend two harvest seasons for the BP system, because plants declined for all cultivars in 2014. Plants in the MR system, however, were good for at least three harvest seasons.

There are various advantages and disadvantages to each of the two systems that were evaluated. BP preserved soil moisture better than MR treatment, eased the fruit picking process, and required minimal weed removal. Weed control was performed one time in the BP system after planting, whereas the MR system needed weed control three to four times during the first growing season and two to three times per season in the following years. However, the BP system required runner removal two to three times each year and experienced more severe winter crown damage than the MR system. The BP system also yielded slightly less fruit than the MR system and declined after two harvest seasons, whereas the MR system can last at least three harvest seasons. The BP system has a higher establishment cost with more plants and the plastic cover. There is also an environmental issue of the plastic disposal as was also mentioned in Stevens et al. (2009).
Strawberry production is challenging in soils with high $\mathrm{pH} /$ lime, which induces strawberry leaf chlorosis, but this can be corrected with cultivar selection and FeEDDHA applications. Winter damage and late frosts can be managed through cultivar selection and overhead sprinkler installation, respectively. Some cultivars are winter-hardy and tolerant to high soil $\mathrm{pH}$. Growers can grow strawberries successfully with proper cultivar selection, soil fertility, and frost management in high-pH soil at high elevation in the southwest United States or similar areas. Based on this study, the fruit size of the strawberry was small compared with other regions (data not shown), and the high temperatures during fruit development could have contributed to this. Another issue is excessive runners for some cultivars, especially 'L'Amour' and 'Ovation'. Further research is needed to discover ways to increase fruit size and reduce runners.

\section{Literature Cited}

Broschat, T.K. and M.L. Elliot. 2005. Effects of iron source on iron chlorosis and Exserohilum leaf spot severity in Wodyetia bifurcata. HortScience 40:218-220.

Campbell, C.R. and C.O. Plank. 1991. Sample preparation, p. 1-11. In: Owen Plank, C. (ed.). Plant analysis reference procedures for the southern region of the United States. Southern Cooperative Series Bulletin \#368.

Galletta, G.J. and H.J. Swartz. 1984. 1983 evaluation of promising strawberry selections and cultivars at Beltsville, Maryland. Advances in Strawberry Production 3:20-22.

Goos, R.J. and B.E. Johnson. 2000. A comparison of three methods for reducing iron-deficiency chlorosis in soybean. Agron. J. 92:1135-1139.

Guan, G., A. Whidden, and F. Wu. 2013. Strawberry industry outlook. $10 \mathrm{Feb} .2014 .<\mathrm{http} / /$ www.fred.ifas.ufl.edu/pdf/webinar/Guan.pdf>.

Gubler, W.D. and D.M. Eastburn. 1988. Research progress report: Anthracnose in California. Advances in Strawberry Production 7:47-50.

Hokanson, S.C. and C.E. Finn. 2000. Strawberry cultivar use in North America. HortTechnology 10:94-106.

Jamieson, A.R. 2003. 'Annapolis' strawberry. J. Amer. Pomol. Soc. 57:98-99.

Jamieson, A.R., J.P. Prive, R.J.A. Tremblay, P. Hendrickson, K.R. Sanderson, N.L. Nickerson, C.F. Forney, and K.A. Sanford. 2004a. 'Cabot' strawberry. HortScience 39:1778-1780.

Jamieson, A.R., R.J.A. Tremblay, P. Hendrickson, J.P. Prive, N.L. Nickerson, and K.R. Sanderson. 2004b. 'Brunswick' strawberry. HortScience 39:1781-1782.

Jamieson, A.R., R.J.A. Tremblay, J.P. Prive, and K.R. Sanderson. 2009. 'Wendy' strawberry. HortScience 44:836-838.

Lewers, K.S., K. Demchak, J.R. Clark, S.A. Garrison, R.C. Funt, S.C. Hokanson, S.Y. Wang, J.M. Enns, G.J. Galletta, and J.L. Maas. 2004. 'Ovation' strawberry. HortScience 39:1785-1788.

Luby, J.J., D.K. Wildung, and G.J. Galletta. 2003. 'MNUS 248' (Mesabi ${ }^{\mathrm{TM}}$ ) strawberry. HortScience 38:481-483.

Moraghan, J.T. 1991. The growth of white lupine on a Calciaquoll. Soil Sci. Soc. Amer. J. 55:13531357.
Poling, E.B. 1993. Strawberry plasticulture in North Carolina. II. Preplant, planting, and postplant considerations for growing 'Chandler' strawberry on black plastic mulch. HortTechnology 3:383-393.

Poling, E.B. and C.D. Safley. 1986. Economics of changing from matted row to annual hill system strawberry production. HortScience 21:14091411.

Pritts, M., G. English-Loeb, and M.J. Kelly. 1999. Strawberry cultivars compensate for simulated bud weevil damage in matted row plantings. HortScience 34:109-111.

Pritts, M. and D. Handley. 1998. Strawberry production guide for the Northeast, Midwest and Eastern Canada. Northeast Regional Agr. Eng. Serv. NRAES-88.

Renquist, A.R. and H.G. Hughes. 1985. Strawberry cultivar evaluation in Colorado: 1982-1984. Advances in Strawberry Production 4:53-55.

Rowley, D., B. Black, D. Drost, and D. Feuz. 2011. Late-season strawberry production using dayneutral cultivars in high-elevation high tunnels. HortScience 46:1480-1485.

Rowley, D., D. Feuz, D. Drost, and B.L. Black. 2010. Early-season extension using Junebearing 'Chandler' strawberry in high-elevation high tunnels. HortScience 45:1464-1469.

Schenkeveld, W.D.C., E.J.M. Temminghoff, V.H. van Riemsdijk, R. Dijcker, and A.M. Reichwein. 2008. The effectiveness of soil-applied FeEDDHA treatments in preventing iron chlorosis in soybean as a function of the o,o-FeEDDHA content. Plant Soil 303:161-176.

Smith, B.R. and L. Cheng. 2006. Fe-EDDHA alleviates chlorosis in 'Concord' grapevines grown at high pH. HortScience 41:1498-1501.

Stevens, M.D., J.A. Abbott, B.L. Black, and J.D. LeaCox. 2007. A comparison of fruit quality and consumer preferences among three cold-climate strawberry production systems. HortTechnology 17:586-591.

Stevens, M.D., P. Downey, E. Pfeil, C.J. Hapeman, R. Rowland, J.D. Lea-Cox, B.L. Black, J. Harman-Fetcho, and A.M. Sadeghi. 2009. A comparison of three cold-climate strawberry production systems: Environmental effects. HortScience 44:298-305.

Stevens, M.D., J. Hapeman, J.D. Lea-Cox, and B.L. Black. 2006. Sustainability of cold-climate strawberry production systems. Acta Hort. 708:69-72.

U.S. Environmental Protection Agency Method 6010A. 1992. Inductively coupled plasma-atomic emission spectrometry. In: Test methods for evaluating solid waste, physical/chemical methods. SW-846, 3rd Ed. U.S. Environmental Protection Agency, Office of Solid Waste and Emergency Response, Washington, D.C.

USDA-National Agriculture Statistics Service. 2014. Agriculture statistics 2012. 10 Feb 2014. <http://www.nass.usda.gov/Publications/ Ag_Statistics/2012/2012_Final.pdf>.

Weber, C. 2005. Geneva strawberry variety trial results 2004. The New York Berry News 4:1-4.

Yao, S., J.J. Luby, and D.K. Wildung. 2009. Strawberry cultivar injury after two contrasting Minnesota winters. HortTechnology 19:803-808.

Yao, S., R. Walser, and C. Martin. 2011. Evaluation of eight apple cultivars and two training systems in northern New Mexico. New Mexico Agr. Exp. Sta. Bul. 803.

Zaiter, H.Z., I. Saad, and H. Niamh. 1993. Yield of iron sprayed and non-sprayed strawberry cultivars grown on high $\mathrm{pH}$ calcareous soil. J. Plant Nutr. 16:281-296. 